\title{
A Review on Virtual Machine Positioning and Consolidation Strategies for Energy Efficiency in Cloud Data Centers
}

\author{
Nahuru Ado Sabongari ${ }^{1}$, Dr. Abdulsalam Ya'u Gital ${ }^{2}$, Prof. Souley Boukari ${ }^{3}$ \\ Badamasi Ja'afaru ${ }^{4}$, Muhammad Auwal Ahmed ${ }^{5}$, Dr. Haruna Chiroma ${ }^{6}$ \\ Dept.of Mathematical Sciences \\ A.T.B.U Bauchi \\ Bauchi, Nigeria
}

\begin{abstract}
The cloud data center consumes massively more and more energy which is considered inacceptable. Therefore further efforts are needed to improve the energy efficiency of such data centers by using Server Consolidation to minimize the number of Active Physical Machines (APMs) in a data center setting. Strategies for positioning and transformation of VM maintain their usefulness as a roadmap to maximum consolidation. The latest techniques do complex restructuring, thus optimizing VM's positioning. The paper provides a detailed state-of - the-art strategies for VM positioning and consolidation that help improve energy efficiency in cloud data centers. A comparison is provided here between the strategies that revealed the worthiness, limitations and suggestions of strengthening other methods along the way.
\end{abstract}

\section{Keywords-Energy efficiency; optimization; cloud data centers}

\section{INTRODUCTION}

Cloud data centers result in high energy consumption and a significant amount of carbon footprints are generated which can be described as the 21st century's biggest challenge. The data center environment is the network that physically houses Cloud computing resources and services (L. Zhang, Yin, Li, \& $\mathrm{Wu}, 2015)$. One of the main reasons for cloud computing's diverse views is that while new technical ideas, new technology, cloud computing has a traditional operating model that brings together a variety of current business management technologies [1, 2]. With a lot of affordable cloud services, and pay as you go. There is a need to at all times have a cheaper, secure, open service with a high demand for cloud service infrastructure and pay as per you go service[3]. Three significant services are made available by the cloud to the user via the Internet. Computing infrastructure as a service (IaaS), with services such as Amazon Elastic Compute Cloud, being supported. Platform as a service (PaaS) to an application of runtime applications, like the Google App Engine[4]. Though Salesforce.com, for instance[5], Software as a Service (SaaS).Although most of these services are provided through virtualization. Virtualization enables the multiple occurrences method to run on one computer[6].Making them shareable among multiple physical users is an abstraction over physical resources [7]. Physical resources are homogeneously virtualized and are therefore efficient for parallel and distributed computing [8]. Distributed cloud systems usually consisting of distributed interconnected data centers, thus using virtualization technologies to provide computing and storage resources for each request on demand [9].

Although cloud computing makes it easier for companies to benefit greatly from lowering operational and administrative costs, the situation suffers from the issue of high energy usage, which could reduce its benefits $[10,11]$. Current studies suggest that data centers produce 78.7 million tons of $\mathrm{CO} 2,2 \%$ of global emissions [12]. CDCs used up to 100 billion kilowatt hours (kWh) in 2015, sufficient for Washington City in the United States alone[12, 13]. By 2022, this high electricity consumption will spread 150 billion $\mathrm{kWh}$, with a 50 per cent increase[14, 15]. If measuring instruments are not, this energy consumption will increase by 2030 in CDCs to 8,000 terawatt hours (TWh). Several prominent cloud providers, including Google, Amazon, Microsoft and IBM, are positive about achieving zero carbon footprint growth and are looking for new ways to render environmentally friendly CDCs and cloud-based services [16, 17]. Such extraordinary energy consumption will lead to excessive carbon dioxide (CO2) emissions which contribute to global warming. VM consolidation is one of the most successful and enabling strategies to reduce energy footprints in cloud data centers [18]. Virtualization offered support with the coming cloud computing, by which it further corroborated the energies for energy-efficient computing. Reducing power usage and energy indulgence had thus become imperative considerations for developing environmentally friendly cloud services [19]. For data centers, major causes of energy inadequacy are the lack of idle power as ICT devices, such as servers, run as long as the processing and storage space is poor in use [20]. The main objective of cloud service providers is to provide a cost-effective and energy-efficient solution for the virtualization of ICT infrastructure for end-user applications following the Service Level Agreement SLA Quality of Service QoS. However, establishing a specific model of energy consumption for VMs remains an open challenge [21].In these devices, however, energy consumption is more desirable and more so. Although the advent of cloud computing has led to massive resource virtualization, due to growing demand for cloud services, their energy cost remains real and rapidly rising [22]. Some of the big challenges of cloud data center days are the amount of electricity consumed 
in a network to complete the application deployment, and the number of workloads executed to the total energy expended by CDC to execute those workloads. The use of energy can be improved if the amount of mechanisms can be increased or reduced to the dynamic power range.. Must of the researcher primarily committed to optimizing the processor and memory energy consumption. Therefore, to spend this research on covering other workloads, such as storage, network bandwidth etc. at the same time, a great deal is needed to facilitate the request of users. This contest of energy efficient cloud services needs to be solved by the future researcher, this can be done by having a good proposal on resource management policies, algorithms, and architectures.

Therefore, because data centers are powered on the combination of grid and renewable energy, it would be wise for cities to save much of their electricity. Consequently, there is a need to handle both resources and QoS effectively together to provide effective Virtual Machine Placement. Most of the current energy-aware resource management techniques and policies focus primarily only on energy-reduction VM server placement, without considering other resources such as networks, storage, memory, and cooling system which consumes huge amounts of energy. This problem can be solved if the energy consumption and SLAs are handled at the same time. Although researchers are currently doing their best on the issue at hand, more is needed to ensure that the Energyefficient and Service Level Agreement (SLA) is reached at the same time to reduce operating costs and meet the needs of consumers.

\section{RELATED WORK}

Cloud computing is growing rapidly, hence the need to look at the data center's cost and efficiency. Service providers draw customers who provide this service with high quality at a lower cost and could be achieved if that physical machine energy is also a bargain in demand to fulfill SLA. Indeed my researcher has already started this data center's energyefficiency policies.

The author in [23] argued that successful energy management is indeed crucial in cloud data centers and therefore appropriate techniques remain important for energy efficient allocation of VMs.

In [24], the author suggested that a constructive way of consolidating would be primarily to explain the VM placement algorithms and procedures used to find an optimal solution to the VM placement issue. These approaches, whichever minimizes power consumption or provides QoS, might be the biggest conflicting target. Ranking these algorithms or selecting the best one could be a very difficult task to suggest since all other placement approaches have specific targets, such as relocation, resources, and powerful parameters. Although it was suggested that these methods might seem outwardly appropriate, some or the other kind of trade-offs still occur when measured in depth.

The author in [25] proposed that the system, given the significant advantages of cloud computing, is still not mature enough to reach its full potential. The various key challenges this area faces, which include automated resource provisioning, power management, and security management that are just starting to get the attention of the research community. For now, huge potential for researchers to make creative contributions in this field will save substantial impact on the growth of the industry.

Author in [19] suggested that energy efficient allocation of resources remains an open challenge. This where it discusses software and hardware-based techniques. The research proposes a taxonomy aspect namely on objective purpose, allocation process, resource adaptation policy, allocation operation, and interoperability.

Author in [26] explore state-of-the-art techniques for maximizing bandwidth, DVF facilitates power management, server consolidation schemes, and methods for optimizing efficiency across WAN connections. Virtual machine migration work critical through an extensive analysis of existing schemes. To conclude, open research questions and trends in the VM migration domain need to be considered to improve further.

It's said that in [27], the extraordinary impertinence that genuine cloud markets are mostly thousands to millions of dynamically generated and destroyed VMs. No agreed criterion for issues with VMP studies depending on the study. And picking up a test question during experimental research should be useful.

The author in [26] proposed a data management and indexation of the big data taxonomy techniques. The aim is to study the indexing needs of big data for the current state-of the-art probability indexing techniques by providing researchers with a basis for designing improved solutions for a specific field to support heterogeneity, scalability and accuracy of data as a major concern. The study is based on the precision of collaborative artificial intelligence techniques for extracting information. The proposed method is based on indexing techniques for easy indexing and retrieval, which as the major issue of BD-MCC is acceptable for large size data. The methods provide acceptable data recovery rate and accuracy in the cloud, and end users always use and capture data wherever they are.

In [28], the author applied the method cumulative energy efficiency CEE provides for a direct comparison of servers and IT devices used in data center, taking into account all infrastructures and the different stages in its lifecycle, and various operating conditions. Evaluate maximum energy consumption of data center facilities, establishes a resource metric efficiency that allows a comparison of products throughout their entire life cycle in a data center. Where the result can be used to improve design, operation, and end-of life strategies for decision makers.

The author in [29] used energy-saving strategies at the data center, with an emphasis on the energy efficiency effect of airflow distribution. Bearing in mind the formation of the thermal environment, multi-scale factors affecting the thermal environment simplify and validate thermal models. This would lead to accurately predict and evaluate the thermal environment and to optimize data center thermal environment 
have become problems that is important to the data center lifespan.

Author in [14] proposes a Total Energy Management forProfessional Data CentersTEMPRO Analytics framework approach will allow for the preliminary evaluation of the energy efficiency of data centers by means of a visualization with consideration of conformity testing of accredited KPIs. The result shows in some certain areas of data centers, they will be used to optimize overall energy effectiveness. Moreover, it suggested the solution would include different means of visualization for a preliminary evaluation, such as the Sankey diagrams.

\section{TAXonomy of Virtual Machine Placement TECHNIQUES}

There are a number of virtual machine techniques for energy efficiency which have centered in a cloud environment on the subject of energy efficient and resource management. Accordingly, the section contrasts the following dimensions: energy policy adaptation, allocation process and energy usage.

Number of VMP taxonomy for the definition in the literature presented here has been studied. Around 40 research article related to the current study where chosen, with various possible question of formulation. Indeed, selecting the best host to deploy a virtual machine known as VMP is a procedure [30]. These formulations can be either power conscious, or service quality. Consequently, it has also broken down into whether it is an artificially intelligent, nonartificially intelligent or collaborative process of power consumption or service quality.

\section{A. Virtual Machine Placement Policy}

Several researchers have tried to work on successful solutions aimed at reducing data center energy consumption while maintaining preferred QoS (Service Quality) [31]. QoS and power saving are two key VM consolidation goals [24]. This type of VM placement method differs from one cloud service provider to another according to the placement target, a VM placement algorithm can generally be divided into two types: Power-based approach with goals of achieving a VMPM mapping resulting in a system that is energy-efficient with the highest use of resources [32]. While QoS-based a VM placement method varies from one cloud service provider to another.

Indecisions arise from a number of issues that may be resource volume demand (e.g. bandwidth, electricity, and storage space), while failure (e.g., network connection failure and CPU hosting instance failure) and user load configuration (e.g. number of users and location) may occur. The paper is based on the strategy of Virtual Machine Placement Techniques divided into two categories: Power consumption and quality of service as contained in Fig. 1.

Cloud-based Hardware resource status can track e, g. Network, virtual server, and storage while software resources such as application servers, web servers, database servers, etc. all constitute basic functionality and virtual machine placement techniques implementation policies. Monitoring operation includes dynamically profiling the QoS parameters that are connected to the hardware and software resources, the physical resources that are shared while the applications run on them or storing the data. Monitoring services can help to position a virtual machine with respect to: maintaining the energy efficiency level at peak activity for applications and cloud resources, monitoring the energy efficiency and service quality (QoS) provided to the host application, and tracking resource and device failures.

Fig. 2 is a tool that helps you get a perfect understanding of categorizing your organization. Based on the above existing methods, categorized in three categories: NAI, AI, and Hybrid. The latest virtual machine placement strategies that are being analyzed in this survey to see their energy efficiency suitability. Placement strategies are listed in categories as Non-artificial intelligence, artificial intelligence, and hybrid are power consumption and quality of service with subcategories. From the above sub-categorization, AI is based on artificial intelligent power consumption or service quality techniques, for example. Ant colony algorithm, Firefly algorithm, Particle swan algorithm, etc., though NAI is such an algorithm that is not, for example, based on artificial intelligent. Greedy algorithm, Heuristic, Best Fit Decreasing etc. but Hybrid is the combination of artificial and nonartificial intelligent or either called hybrid algorithm.

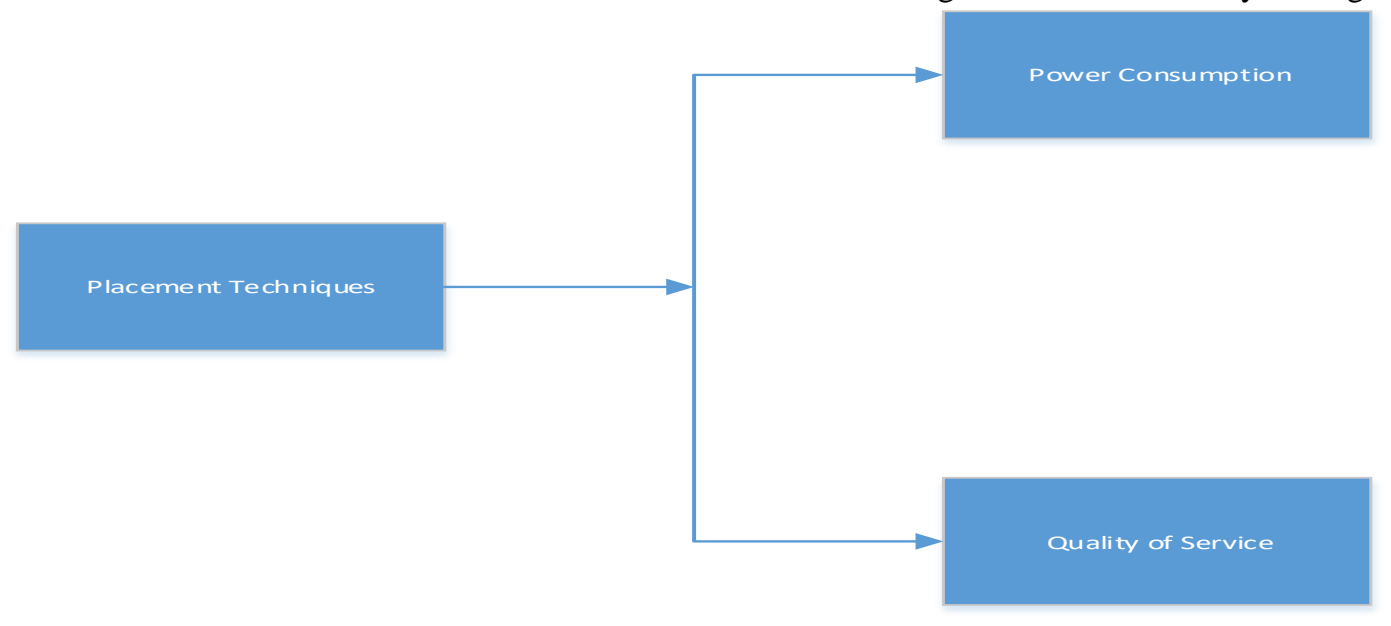

Fig. 1. Types of Placement Techniques. 


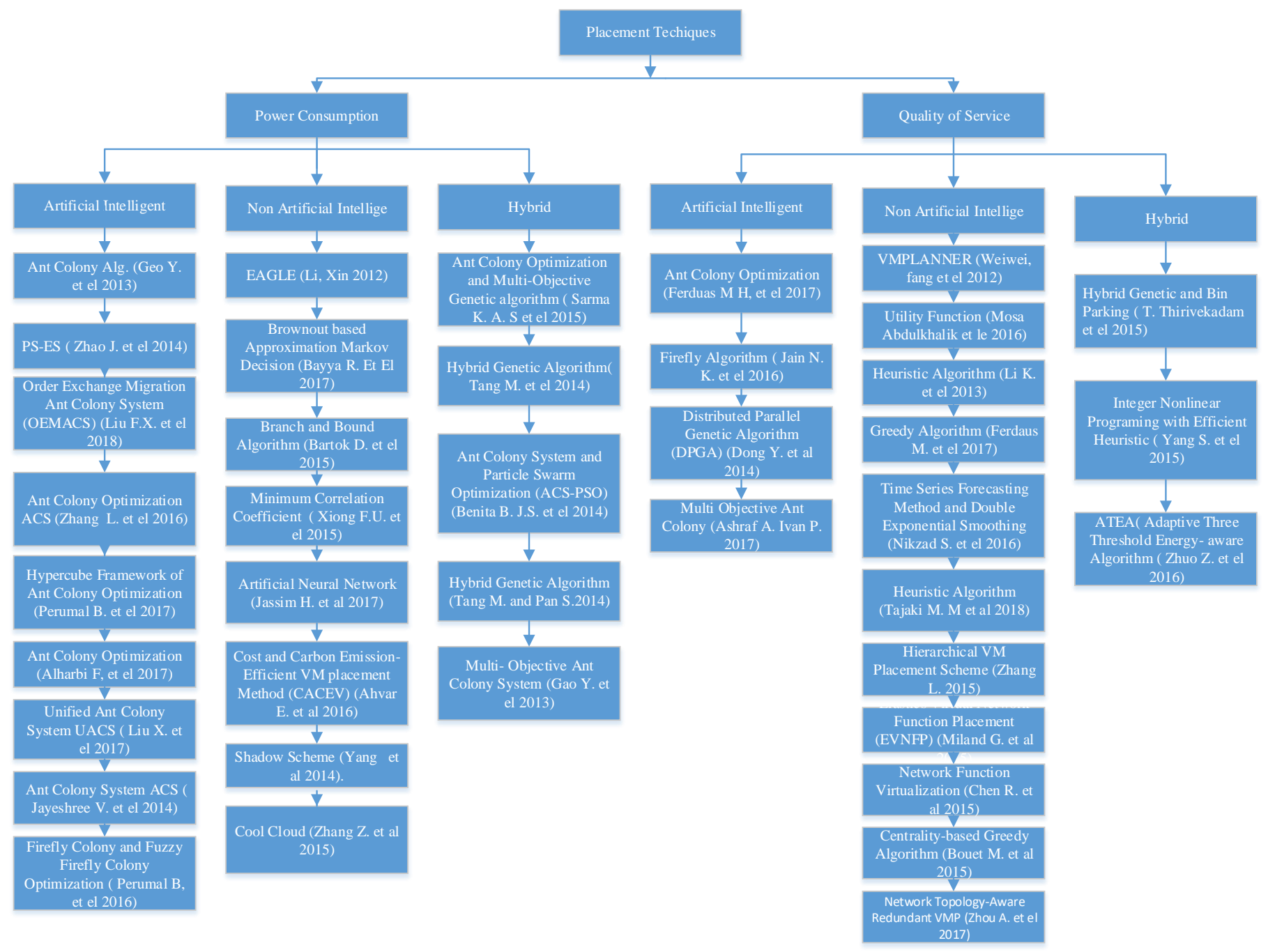

Fig. 2. Taxonomy of Placement Techniques.

Artificial intelligence relates to highly technical and specialized techniques which use the knowledge base when placing a virtual machine to deliver energy efficiency and quality of service. This category is similar to ant colony optimization algorithm, particle swarm algorithm, firefly algorithm, genetic algorithm, etc. This is one of the highly effective methods of power consumption and quality of service in a cloud datacenter.

Non-Artificial Intelligence means placing strategies that are transparent in terms of energy use and quality of service. These techniques are developed mostly for the rapid and efficient placement of virtual machine data. They deploy techniques that include Heuristic optimization algorithm, Greedy algorithm, can best fit, optimizing utility function algorithm, etc. Such non-artificial intelligence strategies are classified as the rule-based automated placement applies only cover-known patterns and cannot identify the data center's unknown behavior.

Hybrid Placement based techniques Hybrid develops energy efficiency and service quality. Such approaches combine AI in a data center to obtain a better supporting solution for virtual machine placement indexing. Some of the techniques in this group are Hybrid Genetic Bin Parking Algorithm, Ant Colony System Particle Swarm optimization, ATEA etc. The significant advantage of the hybrid virtual machine placement classifier is flexibility, so it can be applied to any result of classification (Fig. 3 to 6 graphical representation of the techniques). 


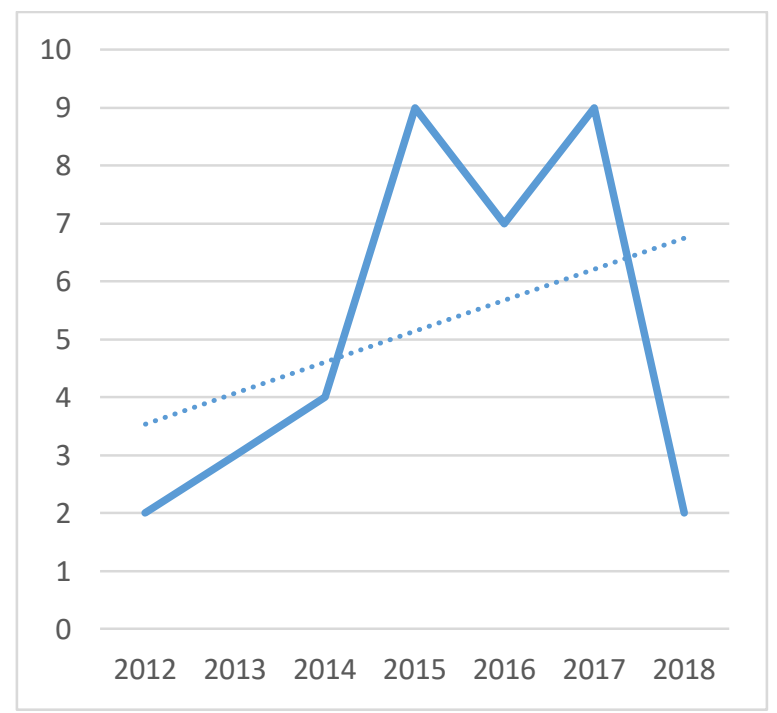

Fig. 3. Virtual Machine Placement Techniques Review Per Year.

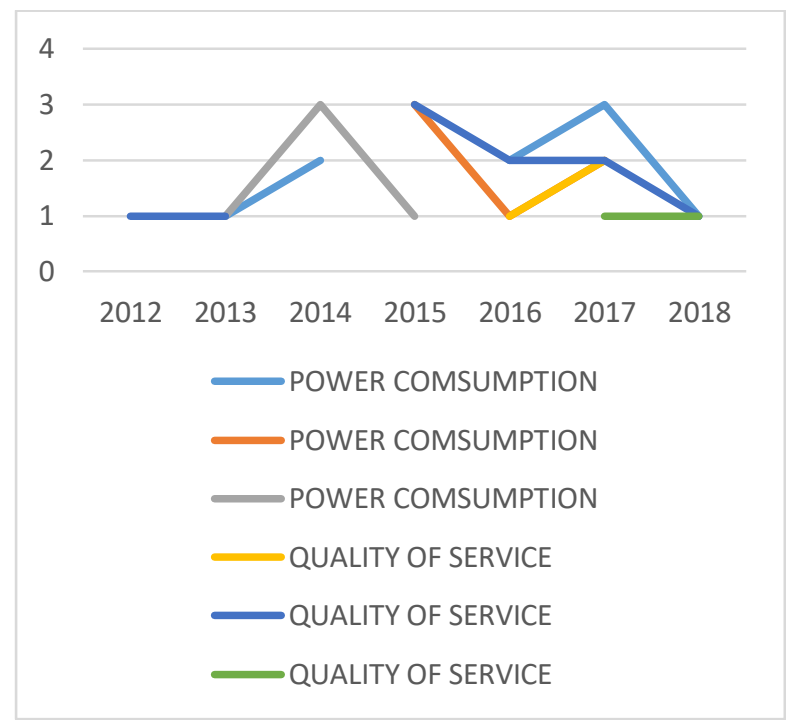

Fig. 4. Per Year Virtual Machine Techniques.

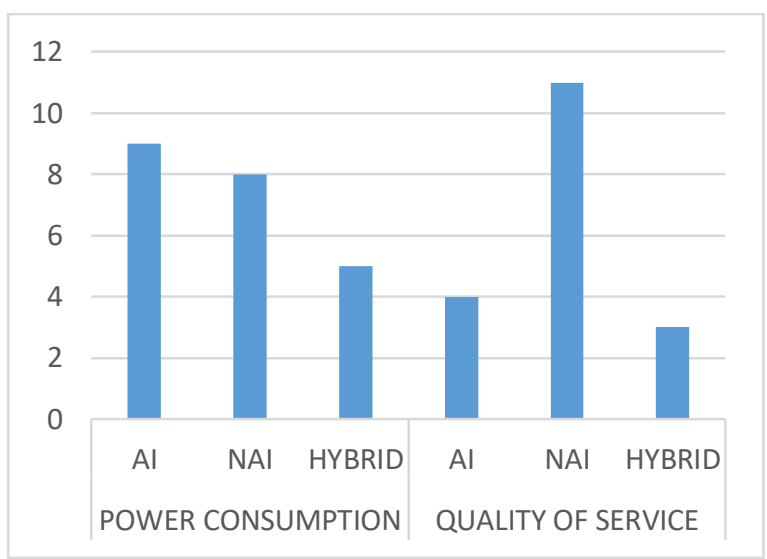

Fig. 5. Types of Virtual Machine Placement Techniques.

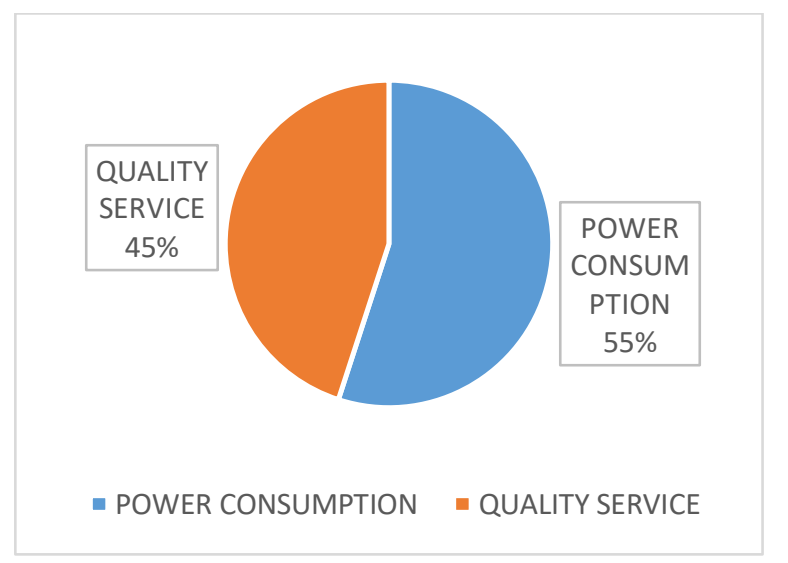

Fig. 6. Virtual Machine Placement Techniques.

\section{Performance Evaluation}

As contained in Table I, power-based restructuring allows the efficient use of resources available thereby violating QoS and breaching SLA constraints. Most algorithms therefore find CPU only as their primary resource and should therefore be extended to take into account other important resources which cannot be relegated.

TABLE I. PERFormance EVAluation

\begin{tabular}{|c|c|c|c|c|c|c|c|}
\hline Author/Date & Metrics & $\begin{array}{l}\text { Metrics } \\
\text { Parameter }\end{array}$ & $\begin{array}{l}\text { Optimization } \\
\text { Parameter }\end{array}$ & Method Applied & Method objective & $\begin{array}{l}\text { Open Research } \\
\text { Challenge }\end{array}$ & $\begin{array}{l}\text { Method } \\
\text { compared }\end{array}$ \\
\hline [33] & $\begin{array}{l}\text { Power } \\
\text { Optimization }\end{array}$ & Multi-Objective & $\begin{array}{l}\text { CPU and } \\
\text { Memory }\end{array}$ & $\begin{array}{l}\text { Order Exchange and } \\
\text { Migration Ant Colony } \\
\text { System (OEMACS) }\end{array}$ & $\begin{array}{l}\text { Resource } \\
\text { efficiency and } \\
\text { energy saving }\end{array}$ & $\begin{array}{l}\text { Did not consider } \\
\text { the quality of } \\
\text { service of the } \\
\text { virtual machine } \\
\text { resources }\end{array}$ & $\begin{array}{l}\text { Heuristic } \\
\text { algorithm }\end{array}$ \\
\hline [34] & $\begin{array}{l}\text { Quality of Service } \\
\text { (QoS) }\end{array}$ & Multi-Objective & $\begin{array}{l}\text { CPU and } \\
\text { Memory }\end{array}$ & $\begin{array}{l}\text { Unified Ant Colony } \\
\text { System (UACS) }\end{array}$ & $\begin{array}{l}\text { Efficient Virtual } \\
\text { Machine } \\
\text { Migration and } \\
\text { Quality of service }\end{array}$ & $\begin{array}{l}\text { The method does } \\
\text { not consider } \\
\text { network } \\
\text { bandwidth }\end{array}$ & $\begin{array}{l}\text { Heuristic } \\
\text { algorithm }\end{array}$ \\
\hline [35] & $\begin{array}{l}\text { Power } \\
\text { Optimization }\end{array}$ & Multi-Objective & $\begin{array}{l}\text { CPU and } \\
\text { Memory }\end{array}$ & $\begin{array}{l}\text { Ant Colony System } \\
\text { (ACS) }\end{array}$ & $\begin{array}{l}\text { Total energy } \\
\text { consumption }\end{array}$ & $\begin{array}{l}\text { The method did } \\
\text { not consider } \\
\text { network } \\
\text { bandwidth quality } \\
\text { of service of the } \\
\text { resources }\end{array}$ & $\begin{array}{l}\text { Compared with } \\
\text { existing Ant } \\
\text { Colony } \\
\text { Algorithm }\end{array}$ \\
\hline
\end{tabular}


(IJACSA) International Journal of Advanced Computer Science and Applications,

Vol. 11, No. 6, 2020

\begin{tabular}{|c|c|c|c|c|c|c|c|}
\hline [36] & $\begin{array}{l}\text { Power } \\
\text { Optimization }\end{array}$ & Multi-Objective & $\begin{array}{l}\text { CPU and } \\
\text { Memory }\end{array}$ & $\begin{array}{l}\text { Firefly Colony and } \\
\text { Fuzzy Colony }\end{array}$ & $\begin{array}{l}\text { Energy efficiency } \\
\text { and resource } \\
\text { wastage }\end{array}$ & $\begin{array}{l}\text { The approach fails } \\
\text { to consider the } \\
\text { standard of } \\
\text { resource service }\end{array}$ & $\begin{array}{l}\text { Better than } \\
\text { Heuristic and } \\
\text { metaheuristic } \\
\text { algorithms }\end{array}$ \\
\hline [37] & $\begin{array}{l}\text { Power } \\
\text { Optimization }\end{array}$ & Multi-Objective & $\begin{array}{l}\text { CPU and } \\
\text { Memory }\end{array}$ & $\begin{array}{l}\text { Multi-objective device } \\
\text { for ant colony }\end{array}$ & $\begin{array}{l}\text { Waste of } \\
\text { resources, and } \\
\text { energy } \\
\text { consumption }\end{array}$ & $\begin{array}{l}\text { Didn't consider } \\
\text { data center } \\
\text { combination } \\
\text { issues }\end{array}$ & $\begin{array}{l}\text { Multifunctional } \\
\text { genetic } \\
\text { algorithm, Bin } \\
\text { parking } \\
\text { algorithm and } \\
\text { Ant Colony } \\
\text { algorithm max- } \\
\text { min }\end{array}$ \\
\hline [38] & $\begin{array}{l}\text { Power } \\
\text { Optimization }\end{array}$ & Multi-Objective & $\begin{array}{l}\text { CPU and } \\
\text { Memory }\end{array}$ & $\begin{array}{l}\text { Hypercube Framework } \\
\text { Ant Colony System }\end{array}$ & $\begin{array}{l}\text { Power } \\
\text { consumption and } \\
\text { resource wastage }\end{array}$ & $\begin{array}{l}\text { Did not take care } \\
\text { of Quality of } \\
\text { Service of } \\
\text { resource }\end{array}$ & $\begin{array}{l}\text { Similar to the } \\
\text { ant system } \\
\text { Max-Min and } \\
\text { Ant colony }\end{array}$ \\
\hline [39] & $\begin{array}{l}\text { Power } \\
\text { Optimization }\end{array}$ & Hybrid & $\begin{array}{l}\text { CPU and } \\
\text { Memory }\end{array}$ & $\begin{array}{l}\text { Multi-Objective and } \\
\text { Ant Colony System }\end{array}$ & $\begin{array}{l}\text { Power efficiency } \\
\text { and resource } \\
\text { utilization }\end{array}$ & $\begin{array}{l}\text { Not consider } \\
\text { network traffic }\end{array}$ & $\begin{array}{l}\text { Compared with } \\
\text { Multi- } \\
\text { Objective } \\
\text { genetic } \\
\text { algorithm }\end{array}$ \\
\hline [40] & Quality of Service & Multi-Objective & $\begin{array}{l}\text { Network } \\
\text { bandwidth }\end{array}$ & VMPlanner & $\begin{array}{l}\text { Traffic demand } \\
\text { and capacity } \\
\text { supply }\end{array}$ & $\begin{array}{l}\text { The algorithm did } \\
\text { not Consider } \\
\text { resource } \\
\text { utilization }\end{array}$ & NA \\
\hline [41] & Quality of Service & Multi-Objective & $\begin{array}{l}\text { CPU and } \\
\text { Memory }\end{array}$ & EAGLE & $\begin{array}{l}\text { Balance the } \\
\text { resource } \\
\text { utilization, reduce } \\
\text { the running PM } \\
\text { and lower the } \\
\text { energy } \\
\text { consumption }\end{array}$ & $\begin{array}{l}\text { The algorithm did } \\
\text { not take care of } \\
\text { Network } \\
\text { communication of } \\
\text { the data center }\end{array}$ & $\begin{array}{l}\text { The algorithm } \\
\text { outperforms } \\
\text { the first-fit } \\
\text { algorithm. }\end{array}$ \\
\hline [42] & Quality of Service & Multi-Objective & $\begin{array}{l}\text { CPU and } \\
\text { Memory }\end{array}$ & $\begin{array}{l}\text { Utility function / } \\
\text { Genetic algorithm }\end{array}$ & $\begin{array}{l}\text { Energy } \\
\text { optimization and } \\
\text { SLA } \\
\end{array}$ & $\begin{array}{l}\text { Did not consider } \\
\text { Network traffic of } \\
\text { the data center }\end{array}$ & $\begin{array}{l}\text { Capered with } \\
\text { Heuristic based } \\
\text { algorithm }\end{array}$ \\
\hline [43] & $\begin{array}{l}\text { Power } \\
\text { Optimization }\end{array}$ & Multi-Objective & $\begin{array}{l}\text { CPU and } \\
\text { Memory }\end{array}$ & $\begin{array}{l}\text { Ant Colony } \\
\text { Optimization (ACO) } \\
\text { Metaheuristic }\end{array}$ & $\begin{array}{l}\text { Reduce energy } \\
\text { consumption, } \\
\text { resource wastage, } \\
\text { and migration } \\
\text { overhead }\end{array}$ & $\begin{array}{l}\text { The algorithm did } \\
\text { consider SLA }\end{array}$ & $\begin{array}{l}\text { Compared with } \\
\text { ACO } \\
\text { metaheuristic }\end{array}$ \\
\hline [44] & Quality of Service & Hybrid & $\begin{array}{l}\text { CPU and } \\
\text { Memory }\end{array}$ & $\begin{array}{l}\text { Hybrid Genetic } \\
\text { algorithm }\end{array}$ & $\begin{array}{l}\text { To reduce } \\
\text { resource } \\
\text { utilization and } \\
\text { SLA }\end{array}$ & $\begin{array}{l}\text { The algorithm did } \\
\text { not take care of } \\
\text { energy } \\
\text { consumption } \\
\text { efficiently }\end{array}$ & $\begin{array}{l}\text { Compared with } \\
\text { algorithms } \\
\text { first fit, best fit } \\
\text { and round } \\
\text { robin. }\end{array}$ \\
\hline [45] & Quality of Service & Hybrid & $\begin{array}{l}\text { CPU and } \\
\text { Memory }\end{array}$ & Heuristic algorithm & $\begin{array}{l}\text { To reduce job } \\
\text { completion time }\end{array}$ & $\begin{array}{l}\text { The proposed } \\
\text { algorithm does not } \\
\text { consider SLA }\end{array}$ & $\begin{array}{l}\text { Compared with } \\
\text { the heuristic } \\
\text { algorithms of } \\
\text { best fit and } \\
\text { first fit }\end{array}$ \\
\hline [46] & Quality of Service & Multi-Objective & $\begin{array}{l}\text { CPU and } \\
\text { Network } \\
\text { bandwidth }\end{array}$ & $\begin{array}{l}\text { Network and Data- } \\
\text { aware Placement } \\
\text { (NDAP) }\end{array}$ & $\begin{array}{l}\text { The proposed } \\
\text { algorithm aims to } \\
\text { reduce energy } \\
\text { consumption and } \\
\text { improved network } \\
\text { performance by } \\
\text { reducing delay on } \\
\text { the transmission } \\
\text { packet. }\end{array}$ & $\begin{array}{l}\text { The proposed } \\
\text { algorithm does not } \\
\text { consider SLA }\end{array}$ & NA \\
\hline [47] & $\begin{array}{l}\text { Quality of Service } \\
\text { and Power } \\
\text { Optimization }\end{array}$ & Multi-Objective & $\begin{array}{l}\text { CPU and } \\
\text { Memory }\end{array}$ & $\begin{array}{l}\text { Modified Best Fit } \\
\text { Decreasing Algorithm } \\
\text { (MBFD) with } \\
\text { clustering }\end{array}$ & $\begin{array}{l}\text { The algorithm } \\
\text { lower the energy } \\
\text { consumption, } \\
\text { Service Level } \\
\text { Agreement } \\
\text { Violation SLAV, } \\
\text { and performance } \\
\text { degradation }\end{array}$ & $\begin{array}{l}\text { The proposed } \\
\text { algorithm did not } \\
\text { consider network } \\
\text { traffic in the cloud } \\
\text { data center }\end{array}$ & NA \\
\hline
\end{tabular}




\begin{tabular}{|c|c|c|c|c|c|c|c|}
\hline$[48]$ & $\begin{array}{l}\text { Power } \\
\text { Optimization }\end{array}$ & Multi-Objective & $\begin{array}{l}\text { CPU and } \\
\text { Memory }\end{array}$ & $\begin{array}{l}\text { The proposed a } \\
\text { custom branch-and- } \\
\text { bound algorithm }\end{array}$ & $\begin{array}{l}\text { The algorithm is } \\
\text { to improve the } \\
\text { effectiveness of } \\
\text { cost, application } \\
\text { performance, and } \\
\text { energy } \\
\text { consumption }\end{array}$ & $\begin{array}{l}\text { The algorithm } \\
\text { does not take care } \\
\text { of network traffic } \\
\text { of the data center }\end{array}$ & $\begin{array}{l}\text { Compared with } \\
\text { integer linear } \\
\text { programming } \\
\text { (ILP) }\end{array}$ \\
\hline [49] & $\begin{array}{l}\text { Quality of Service } \\
\text { and Power } \\
\text { Optimization }\end{array}$ & Multi-Objective & $\begin{array}{l}\text { CPU and } \\
\text { Memory }\end{array}$ & $\begin{array}{l}\text { Adaptive Three- } \\
\text { Threshold Energy- } \\
\text { Aware } \\
\text { Algorithm(ATEA) }\end{array}$ & $\begin{array}{l}\text { The algorithm } \\
\text { aims to improve } \\
\text { the energy and } \\
\text { Service; level } \\
\text { agreement } \\
\text { effectively }\end{array}$ & $\begin{array}{l}\text { Is not network } \\
\text { traffic aware } \\
\text { algorithm }\end{array}$ & NA \\
\hline$[50]$ & $\begin{array}{l}\text { Power } \\
\text { Optimization }\end{array}$ & Multi-Objective & $\begin{array}{l}\text { CPU and } \\
\text { Memory }\end{array}$ & $\begin{array}{l}\text { The Proposed Integer } \\
\text { Nonlinear } \\
\text { Programming } \\
\text { (INLP) }\end{array}$ & $\begin{array}{l}\text { The algorithm has } \\
\text { better in } \\
\text { effectiveness in } \\
\text { node ratio and } \\
\text { performance }\end{array}$ & $\begin{array}{l}\text { The running } \\
\text { time is } \\
\text { significantly } \\
\text { larger than all the } \\
\text { heuristics. }\end{array}$ & $\begin{array}{l}\text { The algorithm } \\
\text { is compared } \\
\text { with ordinary } \\
\text { integer } \\
\text { nonlinear } \\
\text { programming }\end{array}$ \\
\hline [51] & $\begin{array}{l}\text { Power } \\
\text { Optimization }\end{array}$ & Multi-Objective & $\begin{array}{l}\text { CPU and } \\
\text { Memory }\end{array}$ & $\begin{array}{l}\text { The proposed Firefly } \\
\text { algorithm }\end{array}$ & $\begin{array}{l}\text { The algorithm } \\
\text { have shown better } \\
\text { energy efficiency } \\
\text { and migration }\end{array}$ & $\begin{array}{l}\text { The weakness of } \\
\text { the algorithm does } \\
\text { not consider the } \\
\text { Service Level } \\
\text { Agreement }\end{array}$ & $\begin{array}{l}\text { The algorithm } \\
\text { is compared } \\
\text { with Ant } \\
\text { Colony } \\
\text { Optimization } \\
\text { (ACO) and } \\
\text { First Fit } \\
\text { Decreasing } \\
\text { (FFD) } \\
\text { algorithms }\end{array}$ \\
\hline$[52]$ & $\begin{array}{l}\text { Power } \\
\text { Optimization }\end{array}$ & $\begin{array}{l}\text { Hybrid } \\
\text { Objective }\end{array}$ & $\begin{array}{l}\text { CPU and } \\
\text { Memory }\end{array}$ & $\begin{array}{l}\text { A hybrid genetic } \\
\text { algorithm is proposed }\end{array}$ & $\begin{array}{l}\text { The algorithm is } \\
\text { aimed at } \\
\text { improving } \\
\text { efficiency }\end{array}$ & $\begin{array}{l}\text { The } \\
\text { communication } \\
\text { network is not } \\
\text { taken care }\end{array}$ & $\begin{array}{l}\text { Compared with } \\
\text { existing } \\
\text { heuristic } \\
\text { algorithms }\end{array}$ \\
\hline$[53]$ & $\begin{array}{l}\text { Power } \\
\text { Optimization }\end{array}$ & Multi-Objective & $\begin{array}{l}\text { CPU and } \\
\text { Memory }\end{array}$ & $\begin{array}{l}\text { A proposed minimum } \\
\text { correlation coefficient }\end{array}$ & $\begin{array}{l}\text { The algorithm } \\
\text { aims to reduce } \\
\text { energy } \\
\text { consumption, } \\
\text { migration policy } \\
\text { and service level } \\
\text { agreement in a } \\
\text { cloud data } \\
\text { environment }\end{array}$ & $\begin{array}{l}\text { The result shows } \\
\text { that network } \\
\text { traffic is not } \\
\text { considered }\end{array}$ & $\begin{array}{l}\text { The result is } \\
\text { compared with } \\
\text { PABFD }\end{array}$ \\
\hline [33] & $\begin{array}{l}\text { Power } \\
\text { Optimization }\end{array}$ & Multi-Objective & $\begin{array}{l}\text { CPU and } \\
\text { Memory }\end{array}$ & $\begin{array}{l}\text { A proposed Order } \\
\text { Exchange and } \\
\text { Migration Ant Colony } \\
\text { System algorithm }\end{array}$ & $\begin{array}{l}\text { The algorithm } \\
\text { minimizing the } \\
\text { number of active } \\
\text { servers, } \\
\text { improving } \\
\text { resource } \\
\text { utilization, } \\
\text { balancing } \\
\text { different } \\
\text { resources, and } \\
\text { reducing power } \\
\text { consumption. }\end{array}$ & $\begin{array}{l}\text { Service Level } \\
\text { Agreement and } \\
\text { Network Traffic is } \\
\text { not considered }\end{array}$ & $\begin{array}{l}\text { The algorithm } \\
\text { is compared } \\
\text { with the } \\
\text { Heuristic } \\
\text { algorithm }\end{array}$ \\
\hline$[54]$ & $\begin{array}{l}\text { Power } \\
\text { Optimization }\end{array}$ & Multi-Objective & $\begin{array}{l}\text { CPU, } \\
\text { Memory, and } \\
\text { Bandwidth }\end{array}$ & $\begin{array}{l}\text { A Virtual Machine } \\
\text { Placement } \\
\text { biogeography-based } \\
\text { optimization } \\
\text { (VMPBBO) algorithm } \\
\text { is proposed }\end{array}$ & $\begin{array}{l}\text { The algorithm } \\
\text { takes care of } \\
\text { power } \\
\text { consumption and } \\
\text { resource waste at } \\
\text { the same time }\end{array}$ & $\begin{array}{l}\text { The Proposed } \\
\text { algorithm does not } \\
\text { consider Service } \\
\text { Level Agreement } \\
\text { (SLA) }\end{array}$ & $\begin{array}{l}\text { Compared with } \\
\text { Modified } \\
\text { General } \\
\text { Greedy } \\
\text { Algorithm and } \\
\text { Virtual } \\
\text { Machine } \\
\text { Placement Ant } \\
\text { Colony System } \\
\text { (MGGA and } \\
\text { VMPACS) }\end{array}$ \\
\hline
\end{tabular}




\begin{tabular}{|c|c|c|c|c|c|c|c|}
\hline [55] & $\begin{array}{l}\text { Power } \\
\text { Optimization }\end{array}$ & Multi-Objective & $\begin{array}{l}\text { CPU and } \\
\text { Memory }\end{array}$ & $\begin{array}{l}\text { The proposed Ant } \\
\text { Colony System with } \\
\text { Particle Swarm } \\
\text { Optimization } \\
\text { algorithm (ACS-PSO) }\end{array}$ & $\begin{array}{l}\text { The proposed } \\
\text { algorithm aim at } \\
\text { minimizing } \\
\text { resource wastage, } \\
\text { minimizing power } \\
\text { consumption and } \\
\text { for load balancing } \\
\text { in physical } \\
\text { servers. }\end{array}$ & $\begin{array}{l}\text { The algorithm } \\
\text { does not take care } \\
\text { of SLA and } \\
\text { Network Traffic }\end{array}$ & $\begin{array}{l}\text { compared with } \\
\text { the multi- } \\
\text { objective and } \\
\text { ant colony } \\
\text { system } \\
\text { algorithm }\end{array}$ \\
\hline [56] & $\begin{array}{l}\text { Power } \\
\text { consumption and } \\
\text { Quality of Service }\end{array}$ & Multi-Objective & $\begin{array}{l}\text { Network } \\
\text { bandwidth }\end{array}$ & $\begin{array}{l}\text { Network-topology } \\
\text { aware redundant VM } \\
\text { placement approach to } \\
\text { minimizing } \\
\text { the consumption of } \\
\text { network resources }\end{array}$ & $\begin{array}{l}\text { The proposed } \\
\text { approach is a } \\
\text { three-step } \\
\text { process: host } \\
\text { server selection, } \\
\text { optimal redundant } \\
\text { VM } \\
\text { placement, and } \\
\text { recovery strategy } \\
\text { decision }\end{array}$ & $\begin{array}{l}\text { The algorithm } \\
\text { does not take care } \\
\text { of SLA }\end{array}$ & $\begin{array}{l}\text { The algorithm } \\
\text { where } \\
\text { compared with } \\
\text { the heuristic } \\
\text { algorithm }\end{array}$ \\
\hline [57] & Quality of Service & Multi-Objective & $\begin{array}{l}\text { Network } \\
\text { bandwidth }\end{array}$ & $\begin{array}{l}\text { Proposed near optimal } \\
\text { approximation } \\
\text { algorithms }\end{array}$ & $\begin{array}{l}\text { Provide bi-criteria } \\
\text { solutions reaching } \\
\text { constant } \\
\text { approximation } \\
\text { factors with } \\
\text { respect to } \\
\text { the overall } \\
\text { performance, and } \\
\text { adhering to the } \\
\text { capacity } \\
\text { constraints } \\
\text { of the networking } \\
\text { infrastructure by a } \\
\text { constant factor as } \\
\text { well }\end{array}$ & $\begin{array}{l}\text { The algorithm } \\
\text { does not take care } \\
\text { of SLA }\end{array}$ & $\begin{array}{l}\text { Compared with } \\
\text { many realistic } \\
\text { algorithms }\end{array}$ \\
\hline [58] & $\begin{array}{l}\text { Power } \\
\text { consumption and } \\
\text { Quality of Service }\end{array}$ & Multi-Objective & $\begin{array}{l}\text { CPU and } \\
\text { Memory }\end{array}$ & $\begin{array}{l}\text { A Cool Cloud } \\
\text { algorithm is proposed }\end{array}$ & $\begin{array}{l}\text { The algorithm } \\
\text { provides better } \\
\text { power } \\
\text { consumption and } \\
\text { load balancing }\end{array}$ & $\begin{array}{l}\text { The algorithm } \\
\text { does not take care } \\
\text { of SLA }\end{array}$ & $\begin{array}{l}\text { The algorithm } \\
\text { compared with } \\
\text { ILP and } \\
\text { Heuristic }\end{array}$ \\
\hline \multirow[t]{2}{*}{ [59] } & Quality of Service & Multi-Objective & $\begin{array}{l}\text { CPU and } \\
\text { Memory }\end{array}$ & $\begin{array}{l}\text { A shadow routing } \\
\text { based dynamic }\end{array}$ & $\begin{array}{l}\text { The algorithm } \\
\text { shows more } \\
\text { energy efficiency }\end{array}$ & $\begin{array}{l}\text { The algorithm } \\
\text { does not consider } \\
\text { network } \\
\text { infrastructure }\end{array}$ & $\begin{array}{l}\text { The algorithm } \\
\text { is compared } \\
\text { with the } \\
\text { heuristic } \\
\text { algorithm }\end{array}$ \\
\hline & $\begin{array}{l}\text { Power } \\
\text { Consumption }\end{array}$ & Multi-Objective & $\begin{array}{l}\text { CPU, } \\
\text { Bandwidth } \\
\text { and Response } \\
\text { time }\end{array}$ & Cielo algorithm & $\begin{array}{l}\text { The algorithm } \\
\text { theoretically } \\
\text { ensures that every } \\
\text { application has an } \\
\text { evolutionarily } \\
\text { stable positioning } \\
\text { strategy, which is } \\
\text { a constant } \\
\text { solution under a } \\
\text { given workload } \\
\text { and availability of } \\
\text { resources in a } \\
\text { cloud }\end{array}$ & $\begin{array}{l}\text { The algorithm has } \\
\text { less SLA } \\
\text { consideration }\end{array}$ & $\begin{array}{l}\text { an Algorithm is } \\
\text { compared with } \\
\text { the Heuristic } \\
\text { algorithm }\end{array}$ \\
\hline \multicolumn{8}{|c|}{$\begin{array}{l}\text { V. CHALLENGES } \\
\text { Cloud computing is still at a timely stage, as the industry } \\
\text { generally agrees, where a researcher can work. There are } \\
\text { many issues that have not been fully addressed, as the } \\
\text { application of industry poses new challenges. Find this section } \\
\text { summarizing some of the difficult issues related to cloud } \\
\text { computing science. Virtual machine placement algorithms } \\
\text { need to tackle various challenges that come from cloud energy } \\
\text { efficiency model characteristics. Discussing these issues, and } \\
\text { their role in shaping the versatility and convenience offered by }\end{array}$} \\
\hline
\end{tabular}


There is a lot of work that has been checked for the purpose of seeing functionality and restricting them when putting VM in the cloud environment. The techniques were divided into a group which included power consumption and service quality. Since power consumption is aimed at a VMPM mapping that result in an energy-efficient system with the best use of resources, while QoS-based approach is VM-PM mapping that certifies the highest satisfaction of the requirements for service quality. Verily, almost all of the algorithms differ in the goal, but most of them are common in the achievement of power efficiency, while the rest are for service quality. The energy efficiency is highly required in all data center operators to minimize operating costs as well as there is a need to meet user needs where service quality is subject to consumer SLA requirement. One of the hardest tasks is determining which of the sub-techniques is most important.

The energy-efficiency resource management can be described as a major challenge in managing virtualized resource pools effectively for us cloud computing service providers. Physical resources, such as CPU cores, disk space, and network bandwidth need to be cut and shared for virtual machines running potentially heterogeneous workloads. In addition to enhancing productivity processes, integrated resource management can also improve the use of data centers and thus reduce energy usage. Achieving these can be achieved by carefully consolidating workload on a smaller number of servers and turning off unused resources. This research area therefore has an endless opening for the researcher, and is still in need of more.

\section{A. Security}

Safety in cloud computing ensures anonymity for the services offered. This model allows data encryption in order to increase the reliability. The' data encryption software' is used to encrypt and decrypt. Service providers are recommended to have the accuracy and reliability of data encryption. Through requesting the key from the key cloud server (KCS), this function can be accomplished through increasing the reliability and the encryption processes. One of the functionality of access control management (ACM) is to approve and authenticate users who access the cloud. Just approved users are allowed to access the cloud to prevent it from attacking. To order to avoid these issues, an intrusion detection program must be used to detect and only allow users to reduce the difficulty.

\section{B. Scalability}

These are the device's functionalities for operating as specified. Cloud computing is adapting its cost-effective approach to increasing demands. There are various scaling types available including vertical scaling, horizontal scaling and diagonal scaling [60]. To test the virtual machine (VM) scalability based on the multi-core system workloads. For the VMs message workload control protocol (TCP), scalability is constrained as compared to multiple threads. To order to improve scalability, other computing areas will require a lot of focus, such as memory architecture, network architecture and overhead computing.

\section{Data Integrity}

Data integrity is the framework that offers scalability, position-independent and a reliable forum for the client. To have data integrity, we need two things which are protection and performance based on public, private key and secret key generation. Confidentiality of information is secured as we encrypt data to prevent unauthorized users [61]. To verify data storage correction and prevent error a universal hash function is required. Recovery is accomplished without mistake, by maintaining confidentiality.

\section{FUTURE DIRECTION}

A coal generating carbon emissions which are detrimental to both humans and the environment is the most recent major source of energy production. Energy consumption is a concern that has been widely recognized in the ICT sector throughout the ICT infrastructure such as a datacenter. To have an efficient cloud computing infrastructure, a scalable design was required that could support in particular the reduction of greenhouse gas (GHG) transmissions in and energy consumption. The high increase in ICT resource and its density directly impacts users' spending more on data center infrastructure as well as on cooling and energy management.

The transfer of data removes delays and reduces power consumption, and the contact pattern between CPUs is important to observe. In fact putting CPUs on the same servers, or similar to them, takes a lot of work. In addition to the energy-efficient VM placement algorithms, the application interface can provide different performance levels for endusers. However, in cloud computing, QoS-conscious VM allocation policies also play a major role. A comprehensive study is needed to identify specific patterns of behavior by cloud and distribution of workloads. Further effort is needed to find the relationship between varying workloads, while an effort should be made to create structures that can minimize SLA trade-offs and provide energy efficiency algorithms. Given the increasing deployment of large-scale, complex workflow applications, cloud computing hosts face more critical challenges in reducing consumption without infringing a certain quality of service.

VM placement has done a virtualized datacenter that can be reconfigured by live migration to preserve operational efficiency as the selection of needed VMs changes over time. It is based on the above comparison and taxonomy, it can be understood that in a cloud computing environment, there are specific holes that are wet to be filled and can open up challenges in the field of energy efficiency. The power consumption reports 55 percent in the literature, while 45 percent is reported as service quality, which demonstrates that there is still a great need to look at the power consumption field in order to be able to provide efficient service to customer needs. To maximize customer satisfaction, there is a need to match power consumption with the quality of service in order to have better service delivery. Hybrid algorithms are needed for simplification to facilitate the resolution of many multi-objective problems.

Most of the existing energy-aware resource management approaches and policies focus primarily on VM consolidation 
to minimize server power consumption only, without considering other resources such as networks, storage, memory, and cooling, which consumes a huge amount of energy. This is one of the big open research problems for the cloud computing community as geographic resource distribution influences network QoS. Unfortunately, the immense amount of simultaneous high-performance data can also consume large amounts of energy. SLAs and QoS t need better energy efficiency at the data center simultaneously to tackle this energy problem. The research community is called upon to do more to ensure energy efficiency and service quality of the cloud data center in order to work towards this direction.

\section{CONCLUSION}

Energy-efficient VM positioning techniques have in years become one of the main research areas at the data center. In defining the power, quality of service, energy in hardware and software, and categorizing existing literature techniques along with a description of their characteristics and constraints. The paper provides the cloud data center with a categorization of current VM positioning strategies and algorithms. The goal is to determine the VM placement requirements for data from cloud data centers and to present a state-of - the-art potential algorithm that would provide researchers with a basis for designing enhanced solutions in a particular domain to provide flexibility, accuracy and scalability to cloud computing.

Additionally, cloud computing will support the business community due to a large number of cloud services users including mobile apps, online gaming, social media, and email. Cloud services need to be made more energy-efficient and sustainable in this respect which can meet consumer demands in a timely manner without affecting the climate. In addition, to enable energy-efficient cloud services, both energy and QoS must be handled jointly.

\section{REFERENCES}

[1] Sultana, A., Using Hadoop to Support Big Data Analysis: Design and Performance Characteristics. 2015.

[2] Wijayaratne, R., et al., Flexible permission management framework for cloud attached file systems, 2016, Google Patents.

[3] Ranger, S., What is cloud computing? Everything you need to know about the cloud, explained, 2018, Retrieved from ZD Net: https://www. zdnet. com/article/what-is-cloud.

[4] Kavis, M.J., Architecting the cloud: design decisions for cloud computing service models (SaaS, PaaS, and IaaS). 2014: John Wiley \& Sons.

[5] Weissman, C., et al., Method and system for pushing data to a plurality of devices in an on-demand service environment, 2015, Google Patents.

[6] Verdouw, C.N., et al., Virtualization of food supply chains with the internet of things. Journal of Food Engineering, 2016. 176: p. 128-136.

[7] Saleem, M. and J. Rajouri, Cloud computing virtualization. International Journal of Computer Applications Technology and Research, 2017. 6(7): p. 290-292.

[8] Hu, L., et al., Modeling of cloud-based digital twins for smart manufacturing with MT connect. Procedia manufacturing, 2018. 26: $\mathrm{p}$. 1193-1203.

[9] Wu, X., et al., A task scheduling algorithm based on QoS-driven in cloud computing. Procedia Computer Science, 2013. 17: p. 1162-1169.

[10] Beloglazov, A., J. Abawajy, and R. Buyya, Energy-aware resource allocation heuristics for efficient management of data centers for cloud computing. Future generation computer systems, 2012. 28(5): p. 755768.
[11] Jiang, L., et al. Mentornet: Learning data-driven curriculum for very deep neural networks on corrupted labels. in International Conference on Machine Learning. 2018.

[12] Buyya, R. and S.S. Gill, Sustainable cloud computing: foundations and future directions. arXiv preprint arXiv:1805.01765, 2018.

[13] Sharma, Y., B. Javadi, and W. Si, On the reliability and energy efficiency in cloud computing. Parallel and Distributed Computing, 2015. 27: p. 111.

[14] Gizli, V. and J.M. Gómez, A Framework for Optimizing Energy Efficiency in Data Centers, in From Science to Society. 2018, Springer. p. 275-282.

[15] Pompili, D., A. Hajisami, and T.X. Tran, Elastic resource utilization framework for high capacity and energy efficiency in cloud RAN. IEEE Communications Magazine, 2016. 54(1): p. 26-32.

[16] Gill, S.S. and R. Buyya, A taxonomy and future directions for sustainable cloud computing: 360 degree view. ACM Computing Surveys (CSUR), 2018. 51(5): p. 1-33.

[17] Shuja, J., et al., Sustainable cloud data centers: a survey of enabling techniques and technologies. Renewable and Sustainable Energy Reviews, 2016. 62: p. 195-214.

[18] Ashraf, A., B. Byholm, and I. Porres, Distributed virtual machine consolidation: A systematic mapping study. Computer Science Review, 2018. 28: p. 118-130.

[19] Hameed, A., et al., A survey and taxonomy on energy efficient resource allocation techniques for cloud computing systems. Computing, 2016. 98(7): p. 751-774.

[20] Madni, S.H.H., M.S. Abd Latiff, and Y. Coulibaly, Resource scheduling for infrastructure as a service (IaaS) in cloud computing: Challenges and opportunities. Journal of Network and Computer Applications, 2016. 68: p. $173-200$.

[21] Mastelic, T. and I. Brandic, Recent trends in energy-efficient cloud computing. IEEE Cloud Computing, 2015. 2(1): p. 40-47.

[22] Callau-Zori, M., et al., An experiment-driven energy consumption model for virtual machine management systems. Sustainable Computing: Informatics and Systems, 2018. 18: p. 163-174.

[23] Patel, S. and R.M. Makwana, Optimized Energy Efficient Virtual Machine Placement Algorithm and Techniques for Cloud Data Centers. JCS, 2016. 12(9): p. 448-454.

[24] Usmani, Z. and S. Singh, A survey of virtual machine placement techniques in a cloud data center. Procedia Computer Science, 2016. 78: p. $491-498$.

[25] Zhang, Q., L. Cheng, and R. Boutaba, Cloud computing: state-of-the-art and research challenges. Journal of internet services and applications, 2010. 1(1): p. 7-18.

[26] Ahmad, R.W., et al., A survey on virtual machine migration and server consolidation frameworks for cloud data centers. Journal of network and computer applications, 2015. 52: p. 11-25.

[27] Pires, F.L. and B. Barán. A virtual machine placement taxonomy. in 2015 15th IEEE/ACM International Symposium on Cluster, Cloud and Grid Computing. 2015. IEEE.

[28] Peñaherrera, F. and K. Szczepaniak, Development and Application of Metrics for Evaluation of Cumulative Energy Efficiency for IT Devices in Data Centers, in Cascade Use in Technologies 2018. 2019, Springer. p. $142-153$.

[29] Jin, C., X. Bai, and C. Yang, Effects of airflow on the thermal environment and energy efficiency in raised-floor data centers: A review. Science of The Total Environment, 2019. 695: p. 133801.

[30] Attaoui, W. and E. Sabir, Multi-criteria virtual machine placement in cloud computing environments: a literature review. arXiv preprint arXiv:1802.05113, 2018.

[31] Zhao, J., et al., A heuristic placement selection of live virtual machine migration for energy-saving in cloud computing environment. PloS one, 2014. 9(9): p. e108275.

[32] Beloglazov, A. and R. Buyya. Energy efficient resource management in virtualized cloud data centers. in 2010 10th IEEE/ACM International Conference on Cluster, Cloud and Grid Computing. 2010. IEEE. 
[33] Liu, X.-F., et al., An energy efficient ant colony system for virtual machine placement in cloud computing. IEEE Transactions on Evolutionary Computation, 2018. 22(1): p. 113-128.

[34] Liu, X.-F., Z.-H. Zhan, and J. Zhang, An Energy Aware Unified Ant Colony System for Dynamic Virtual Machine Placement in Cloud Computing. Energies, 2017. 10(5): p. 609.

[35] Alharbi, F., et al. Profile-Based Ant Colony Optimization for EnergyEfficient Virtual Machine Placement. in International Conference on Neural Information Processing. 2017. Springer.

[36] Perumal, B. and A. Murugaiyan, A firefly colony and its fuzzy approach for server consolidation and virtual machine placement in cloud datacenters. Advances in Fuzzy Systems, 2016. 2016: p. 5.

[37] Gao, Y., et al., A multi-objective ant colony system algorithm for virtual machine placement in cloud computing. Journal of Computer and System Sciences, 2013. 79(8): p. 1230-1242.

[38] Perumal, B. and A. Murugaiyan, Virtual Machine Placement Using Hypercube Ant Colony Optimization Framework.

[39] Sarma, V.A.K., et al., An optimal ant colony algorithm for efficient VM placement. Indian Journal of Science and Technology, 2015. 8(S2): p. 156-159.

[40] Fang, W., et al., VMPlanner: Optimizing virtual machine placement and traffic flow routing to reduce network power costs in cloud data centers. Computer Networks, 2013. 57(1): p. 179-196.

[41] Li, X., et al., Energy efficient virtual machine placement algorithm with balanced and improved resource utilization in a data center. Mathematical and Computer Modelling, 2013. 58(5-6): p. 1222-1235.

[42] Mosa, A. and N.W. Paton, Optimizing virtual machine placement for energy and SLA in clouds using utility functions. Journal of Cloud Computing, 2016. 5(1): p. 17.

[43] Ferdaus, M.H., et al., Multi-objective, Decentralized Dynamic Virtual Machine Consolidation using ACO Metaheuristic in Computing Clouds. arXiv preprint arXiv:1706.06646, 2017.

[44] Li, R., et al., Multi-objective optimization for rebalancing virtual machine placement. Future Generation Computer Systems, 2017.

[45] Li, K., H. Zheng, and J. Wu. Migration-based virtual machine placement in cloud systems. in Cloud Networking (CloudNet), 2013 IEEE 2nd International Conference on. 2013. IEEE.

[46] Ferdaus, M.H., et al., An algorithm for network and data-aware placement of multi-tier applications in cloud data centers. Journal of Network and Computer Applications, 2017. 98: p. 65-83.

[47] Chowdhury, M.R., M.R. Mahmud, and R.M. Rahman, Implementation and performance analysis of various VM placement strategies in CloudSim. Journal of Cloud Computing, 2015. 4(1): p. 20.
[48] Bartók, D. and Z.A. Mann. A branch-and-bound approach to virtual machine placement. in Proceedings of the 3rd HPI Cloud Symposium "Operating the Cloud. 2015.

[49] Zhou, Z., Z. Hu, and K. Li, Virtual machine placement algorithm for both energy-awareness and SLA violation reduction in cloud data centers. Scientific Programming, 2016. 2016: p. 15.

[50] Yang, S., P. Wieder, and R. Yahyapour. Reliable virtual machine placement in distributed clouds. in Resilient Networks Design and Modeling (RNDM), 2016 8th International Workshop on. 2016. IEEE.

[51] Kansal, N.J. and I. Chana, Energy-aware virtual machine migration for cloud computing-a firefly optimization approach. Journal of Grid Computing, 2016. 14(2): p. 327-345.

[52] Tang, M. and S. Pan, A hybrid genetic algorithm for the energy-efficient virtual machine placement problem in data centers. Neural Processing Letters, 2015. 41(2): p. 211-221.

[53] Fu, X. and C. Zhou, Virtual machine selection and placement for dynamic consolidation in Cloud computing environment. Frontiers of Computer Science, 2015. 9(2): p. 322-330.

[54] Zheng, Q., et al., Virtual machine consolidated placement based on multi-objective biogeography-based optimization. Future Generation Computer Systems, 2016. 54: p. 95-122.

[55] Suseela, B.B.J. and V. Jeyakrishnan, A multi-objective hybrid ACOPSO optimization algorithm for virtual machine placement in cloud computing. Int. J. Res. Eng. Technol, 2014. 3(4): p. 474-476.

[56] Zhou, A., et al., Cloud service reliability enhancement via virtual machine placement optimization. IEEE Transactions on Services Computing, 2017. 10(6): p. 902-913.

[57] Cohen, R., et al. Near optimal placement of virtual network functions. in Computer Communications (INFOCOM), 2015 IEEE Conference on. 2015. IEEE.

[58] Zhang, Z., C.-C. Hsu, and M. Chang. Cool cloud: A practical dynamic virtual machine placement framework for energy aware data centers. in 2015 IEEE 8th International Conference on Cloud Computing (CLOUD). 2015. IEEE.

[59] Guo, Y., S. Stolyar, and A. Walid, Shadow-routing based dynamic algorithms for virtual machine placement in a network cloud. IEEE Transactions on Cloud Computing, 2015.

[60] Hassan, S. and F. Azam. Analysis of cloud computing performance, scalability, availability, \& security. in 2014 International Conference on Information Science \& Applications (ICISA). 2014. IEEE.

[61] Balusamy, B., et al., Bio-inspired algorithms for cloud computing: a review. International Journal of Innovative Computing and Applications, 2015. 6(3-4): p. 181-202. 